\title{
The structure, phase and chemical composition of CZTSe thin films
}

\author{
A.S.Opanasyuk,P.V.Koval, D.Nam*, H.Cheong*, \\ A.R.Jeong ${ }^{* *}, W^{* J o * *}$, A.G.Ponomarev \\ Sumy State University, 2 Rimsky-Korsakov Str., 40007 Sumy, Ukraine \\ *Sogang University, 1 Shinsu-dong, Mapo-gu, 121-742 Seoul, Korea \\ *: Department of Physics, Ewha Womans University, 120-750 Seoul, Korea \\ $*$ Institute of Applied Physics, National Academy of Sciences of Ukraine, \\ 58 Petropavlovskaya Str., 40000 Sumy, Ukraine
}

\section{Received December 5, 2013}

\begin{abstract}
$\mathrm{Cu}_{2} \mathrm{ZnSnSe}_{4}$ thin films obtained by co-evaporation of components using an electron beam evaporation system were investigated by scanning electron microscopy, X-ray analysis, PIXI and RBS methods. The analysis of the diffraction patterns showed that the films are almost single-phased and contain mainly CZTSe compound, which has a tetragonal kesterite lattice type. The samples have textural growth of [211]. The lattice parameters of the material varied in the range of $a=(0.56640-0.56867) \mathrm{nm}, c=(1.13466-1.13776) \mathrm{nm}$, $c / 2 a=0.9983-1.0017$ which correlate well with the reference data in a stable phase CZTSe compounds. From our PIXE analyses we assessed the influence of the growth conditions on the samples' chemical composition and mapped the surface distribution.
\end{abstract}

Методами сканирующей электронной микроскопии, рентгеноструктурного анализа, PIXI и RBS проведено исследование тонкопленочных образцов $\mathrm{Cu}_{2} \mathrm{ZnSnSe}$, полученных соиспарением компонентов с использованием электронно-лучевой пушки. Анализ дифрактограмм показал, что пленки являются практически однофазными и содержат в основном соединение CZTSe, имеющее тетрагональную кристаллическую решетку типа кистерит. В образцах обнаружена текстура роста [211]. Параметры решетки материала изменялись в диапазоне $a=(0,56640-0,56867)$ нм, $c=(1,13466-1,13776) \mathrm{Hм}, c / 2 a=$ 0,9983-1,0017, что хорошо коррелирует со справочными данными по стабильной фазе соединения CZTSe. Анализ результатов PIXE позволил оценить влияние условий роста на химический состав образцов, построена карта распределения элементов по поверхности образцов.

Структура, фазовий і хімічний склад тонких плівок CZTSe. А.С.Опанасюк, П.В.Коваль, D.Nam, H.Cheong, A.R.Jeong, W.Jo, A.Г.Пономарьов.

Методами скануючої електронної мікроскопії, рентгеноструктурного аналізу, PIXI та RBS проведено дослідження тонкоплівкових зразків $\mathrm{Cu}_{2} \mathrm{ZnSnSe}$, отриманих співвипаровуванням компонентів 3 використанням електронно-променевої гармати. Аналіз дифрактограм показав, що плівки є практично однофазними і містять в основному сполуку CZTSe, яка має тетрагональну кристалічну гратку типу кістерит. У зразках виявлено текстуру росту [211]. Параметри гратки матеріалу змінювалися у діапазоні $a=(0,56640-$ $0,56867)$ нм, $c=(1,13466-1,13776)$ нм, $c / 2 a=0,9983-1,0017$, що добре корелює $з$ довідковими даними за стабільною фазою сполуки CZTSe. Аналіз результатів PIXE дозволив оцінити вплив умов росту на хімічний склад зразків, побудовано карту розподілу елементів повз поверхні зразків. 


\section{Introduction}

Nowadays, the quadruple compounds $\mathrm{Cu}_{2} \mathrm{ZnSnS}_{4}$ (CZTS) and $\mathrm{Cu}_{2} \mathrm{ZnSnSe}_{4}$ (CZTSe) are considered as an alternative to the traditional highly absorbent layers of thin-film solar cells such as CulnSe ${ }_{2}$ (CIS), Culn $_{1-x} \mathrm{Ga}_{x} \mathrm{Se}_{2}$ (CIGS), and CdTe. Its advantages include the band-gap energy of $E_{g}=$ $(1.0-1.5) \mathrm{eV}$, which is optimal for solar conversion, along with its high absorption coefficient $\left(\sim 10^{5} \mathrm{~cm}^{-1}\right), p$-type conductivity, a long charge-carrier lifetime, and also a very high carrier mobility [1,2]. Unlike other semiconductors used today as an absorbing layer in thin-film solar cells, this compound does not contain rare components or environmentally dangerous ones; all its elements are common, and the cost of its production is low compared with that of other such compounds [3,4]. However, certain difficulties are encountered in depositing CZTS(Se) films because the components have very different vapor pressures, and furthermore, the homogeneity of the compound is quite narrow [1]. Consequently, the films often contain several phases with different bandgaps [5-7], which negatively affects the solar cell efficiency by increasing the series and shunt resistances of the devices [8]. The situation is complicated by the fact that the compounds may condense in two phases: kesterite (space group I4) and stannite (space group $142 \mathrm{~m}$ ), and the difference in the formation energies of these phases is small. In this regard, the samples often have two phases. Along with this, the kesterite phase has the optimal parameters as the base layer for solar cells [9].

In recent years, the efficiency of solar cells with CZTS(Se) absorbing layers has significantly increased and reached $12.6 \%$ [10]. The structure of sodium glass/Mo/CZTSSe/CdS/ZnO/ITO/ Ni-Al typically gives the maximum efficiency [11]. At the same time it was found that the efficiency of converters is determined by the composition of four-component compounds. The maximum efficiency of solar cells was obtained with enriched zinc $\left(C_{\mathrm{Zn}} / C_{\mathrm{Sn}} \sim 1.1-1.2\right)$ and depleted copper $\left(C_{\mathrm{Cu}} / C_{(\mathrm{Zn}+\mathrm{Sn})}=0.80-0.85\right)$ absorbing layers [8]. However, the deviation from the stoichiometry of the film contributes to the formation of secondary phases, which, adversely affects the solar cells performances.

The influence of physical and technological conditions of obtaining on the phase composition, structural, optical and electrical characteristics of CZTS compound has been studied [8-12]. On the other hand, the CZTSe compound has been studied much less.

There are several methods of obtaining CZTSe thin films, including magnetron sputtering [12], electro-deposition of precursors $\mathrm{Cu}, \mathrm{Zn}, \mathrm{Sn}$ and annealing in an atmosphere of Se [7,14], spray pyrolysis [15], and thermal co-evaporation of the components $[2,6,16,17]$. We consider that one of the most suitable methods is the thermal co-evaporation of the compound components, because it allows the control of the composition of the films so obtained. However, the physical and technologicalconditions for obtaining the needed composition of the films using this method have been insufficiently explored. This caused the goal of investigations.

\section{Experimental}

We prepared CZTSe films by co-evaporating the components ( $\mathrm{Cu}, \mathrm{Zn}, \mathrm{Sn}$, and Se) using an electron beam evaporation system, where Se were thermally evaporated for high deposition rate. The main e-beam chamber was pumped below $2 \cdot 10^{-6}$ Torr before the deposition using an oil-free cryopump, while an ordinary rotary pump was used during the roughing process. The pressure was maintained under $10^{-5}$ Torr during the growth of the films. The chemical composition of the samples was regulated by the deposition rate and the deposition time of the sources, which is monitored by the SQC310C thickness monitor (Inficon Inc. U.S.A) using gold-coated quartz crystals. The films were deposited on cleaned glass substrate with a $1 \mu \mathrm{m}$ thick conductive Mo layer. The substrate was maintained at a temperature of $400^{\circ} \mathrm{C}$ to minimize the loss of $\mathrm{Sn}$ and the formation of secondary phases during the deposition. For homogenization of the films during the deposition the substrate is rotated. The condensation time was $2 \mathrm{~h}$. The calculated concentrations of the components of the obtained films are shown in Table 1. As the table shows the samples had different stoichiometry, including optimal composition for highly efficient solar cells. Our method of obtaining these data are detailed in $[16,17]$.

The surface morphology was investigated by scanning microscopy. Our structural analysis of the thin films was carried out with a DRON 4-07 X-ray diffractometer using a Ni-filtered $\mathrm{Cu}-\mathrm{K}_{\alpha}$ radiation source in the range of diffraction angles $2 \theta$ from 
Table 1. Thickness and rated composition of the films

\begin{tabular}{||c|c|c|c|c||}
\hline Sample No. & Thickness, $\mu \mathrm{m}$ & $C_{\mathrm{Cu}} / C_{(\mathrm{Zn}+\mathrm{Sn})}$ & $C_{\mathrm{Zn}} / C_{\mathrm{Sn}}$ & Notes \\
\hline 1152 & 1.75 & 0.84 & 0.51 & poor Cu, rich Zn \\
1156 & 1.90 & 0.47 & 1.69 & poor Cu, rich Zn \\
1157 & 2.25 & 1.22 & 1.23 & rich Cu, rich Zn \\
1161 & 1.25 & 0.80 & 1.20 & The optimal composition for solar cell \\
\hline
\end{tabular}

$10^{\circ}$ to $90^{\circ}$, where $2 \theta$ is the Bragg angle. The resulting diffraction pattern was normalized on the (112) peak intensity. The phase analysis was undertaken by comparing the inter-plane distances and relative intensities of the films, and the JCPDS reference data [18].

The inter-plane distances of the tetragonal phase compounds were defined by the positions of the $\mathrm{K}_{\alpha 1}$ component of the most intense lines in the diffractograms. We calculated the lattice constants, $a$ and $c$, of the material using the formulas $[19,20]$ :

$$
\begin{gathered}
a=\frac{\lambda}{2 \sin \theta} \sqrt{h^{2}+k^{2}+l^{2}\left(\frac{a}{c}\right)^{2}}, \\
c=\frac{l}{\sqrt{-\frac{h^{2}+k^{2}}{a^{2}}+\left(\frac{2 \sin \theta}{\lambda}\right)^{2}}}
\end{gathered}
$$

where $\lambda$ is the X-ray wavelength, and $h, k$, $l$ are the Miller indices.

The $a / c$ ratio was considered equal to the value defined in the directory for CZTSe [18]. Furthermore, to obtain precise values of the constants, we used the extrapolation method of Nelson-Riley [20,21]. The values of the tetragonal phase constants $a$ and $c$ were obtained by a graphical method of successive approximations [20]. We calculated the values in equations (1) and (2) for each diffraction line and for those selected crystallographic planes for which the contribution to the sum with an unknown quantity $(a / c, c / a)$ was minimal. The analysis showed that in determining the constant $c$, the most appropriate lines are (316), (112), and (204), whereas for determining $a$, they were lines (316) and (211). Thereafter, the lattice parameters $a$ and $c$ were obtained from this graph, and their ratio was calculated. This procedure was repeated until the values $a$, $c$, and $c / a$ no longer changed.

We estimated the quality of the films' textures by the Harris method. To calculate the tetragonal lattice angle between the axis perpendicular to the textures and different crystallographic planes, we employed the expressions given in $[20,21]$. The average size of the coherent scattering regions $L$ (CSRs), were assessed by the radiographic method using the Debye-Scherrer equation [14-16].

The samples' elemental composition was obtained via micro-analytical range acceleration from a compact electrostatic accelerator "Sokol" with a beam of protons with energies up to $2 \mathrm{MeV}$ (IAP Academy of Sciences of Ukraine, Sumy). For analyzing the films, we evaluated the characteristic X-rays induced by exposing them to a proton beam [22]. The total spectra were taken from several areas of the samples' surfaces; after this, we scanned them stepwise with a micro-beam ( $\mu$-PIXE).

The size of the scan area was $200 \times 200 \mu \mathrm{m}^{2}$, the probe's transverse size was $4 \times 4 \mu \mathrm{m}^{2}$, the charge $Q=4 \cdot 10^{-10} \mathrm{C} / \mathrm{pixel}$, the grid $50 \times 50$ pixels, the scan step $4 \mu \mathrm{m}$, and the proton energy $E_{p}=1.5 \mathrm{MeV}$. Here, a pixel denotes the stationary position of the probe at discrete scan steps. The features of focusing and scanning of the microanalytical accelerator complex are described in [23].

We obtained elemental distribution maps on the samples' surfaces from which we determined the elemental composition of the condensates in several areas. For processing the PIXE spectra, we employed the GUPIX program. To translate data on mass concentration to nuclear $\left(C_{i}\right)$, the expression given in [24] was employed. The elemental composition of the films was obtained by the RBS method [22, 25]. The primary beam of protons impinged on the target at a normal angle. There was an angle of 135 between the direction of the primary beam and the direction of scattering. As the detecting system, we used a magnetic spectrometer and a silicon detector for charged particles. The RBS spectra were processed using programs SIMNRA and DVBS. 


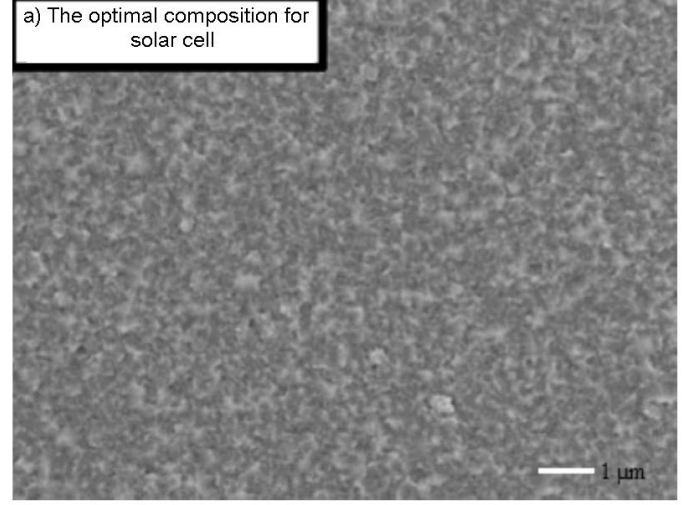

Fig. 1. SEM images of four CZTSe thin films.

\section{Results and discussion}

Fig. 1 shows the electron-microscopic images of the surface of CZTSe films, obtained at different pressures of components. The films had a polycrystalline structure with a grain size of $0.1-1 \mu \mathrm{m}$.

The diffraction patterns are shown in Fig. 2. To simplify the phase analysis, we removed the diffraction peaks from the Mo substrate. X-ray diffraction and Raman spectroscopy [16] showed that the films are almost exclusively single-phased and contained mainly the CZTSe compound, which had a tetragonal lattice. The content of other phases did not exceed a few percent. Typically, the X-ray structure of nonstoichiometric samples exhibited 1-2 lines of low intensity (2-3\%) that did not belong to CZTSe. We interpreted them as being lines of the phases CuSe, CuZn, or Se.

It is known that the intensity ratio of the diffraction reflections from crystallographic planes for the phases of stannite and kesterite is different [2]. That is why we calculated the relationships for experimental diffraction patterns data. It was found that the intensity ratio of reflections
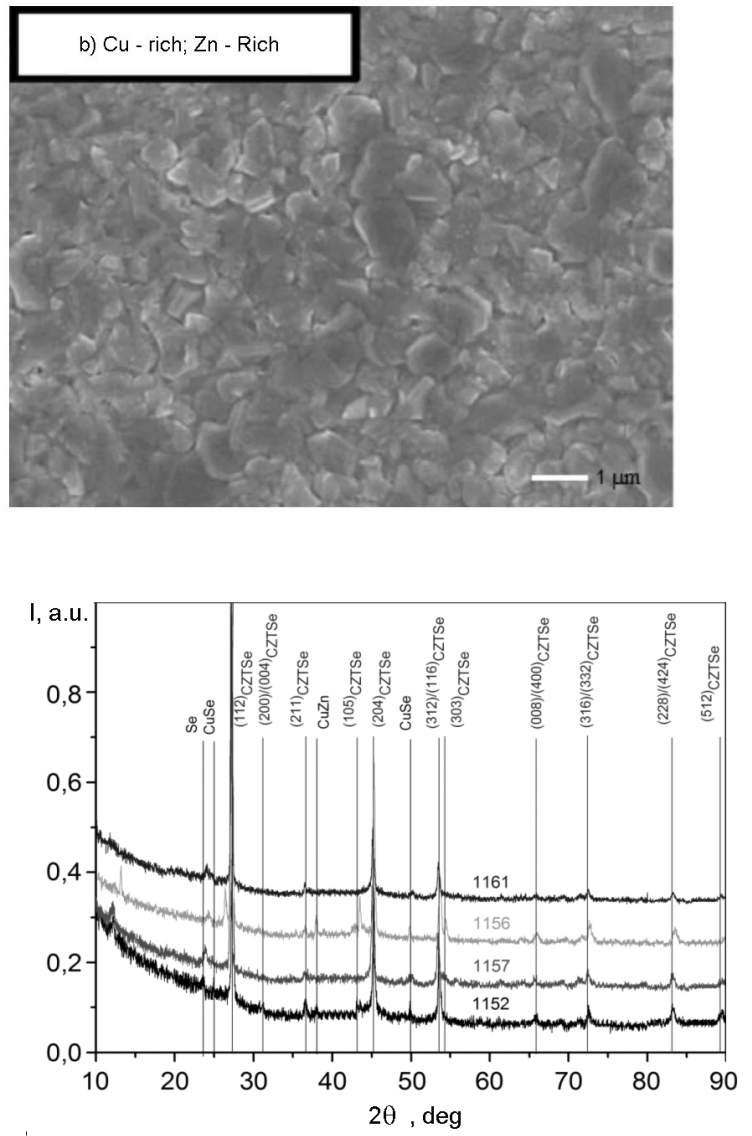

Fig. 2. XRD patterns of the CZTSe films.

from the crystal faces (112) and (204), $I_{(112)} / I_{(204)}$ of the samples is $3.16-4.28$, whereas the ratio $I_{(112)} / I_{(312)}$ is $7.53-7.78$. These values are closer to those obtained for kesterite [2]. Thus, the films investigated are likely to have the kesterite structure.

To confirm this conclusion we identified the lattice parameters of this films and their ratio, as it is well known that for the kesterite structure, the ratio $c / a$ is close to 1 [8].

Table 2 shows the results of determining the lattice parameters of the material after

Table 2. The results of determination structural parameters of the CZTSe films

\begin{tabular}{|c|c|c|c|c|c|c|c|c|c|c|c|c|}
\hline \multirow{2}{*}{$\begin{array}{l}\text { Sam- } \\
\text { ple }\end{array}$} & \multicolumn{3}{|c|}{1 iteration } & \multicolumn{3}{|c|}{4 iteration } & \multicolumn{5}{|c|}{$L, \mathrm{~nm}$} & \multirow[t]{2}{*}{$f$} \\
\hline & $a, \mathrm{~nm}$ & $c, \mathrm{~nm}$ & $c / 2 a$ & $a, \mathrm{~nm}$ & $c, \mathrm{~nm}$ & $c / 2 a$ & (112) & (211) & $(204)$ & $(312)$ & $(316)$ & \\
\hline 1152 & 0.57260 & 1.13530 & 0.9914 & 0.56640 & 1.1347 & 1.0017 & 40.8 & 22.2 & 28.5 & 26.7 & 16.1 & 6.16 \\
\hline 1156 & 0.57260 & 1.13810 & 0.9938 & 0.56831 & 1.13776 & 1.0010 & 48.4 & 28.9 & 32.7 & 26.2 & 20.1 & 1.56 \\
\hline 1157 & 0.57260 & 1.13230 & 0.9887 & 0.56741 & 1.13466 & 0.9999 & 44.4 & 20.0 & 32.4 & 26.1 & 17.2 & 1.58 \\
\hline 1161 & 0.57260 & 1.13230 & 0.9887 & 0.56867 & 1.13537 & 0.9983 & 41.5 & 34.9 & 29.4 & 29.8 & 17.7 & 2.17 \\
\hline $\begin{array}{l}\text { Direc- } \\
\text { tory }\end{array}$ & \multicolumn{6}{|c|}{$\begin{array}{c}a=0.56930 \mathrm{~nm}, c=1.13330 \mathrm{~nm} \\
c / 2 a=0.9954[18]\end{array}$} & & & & & & \\
\hline
\end{tabular}



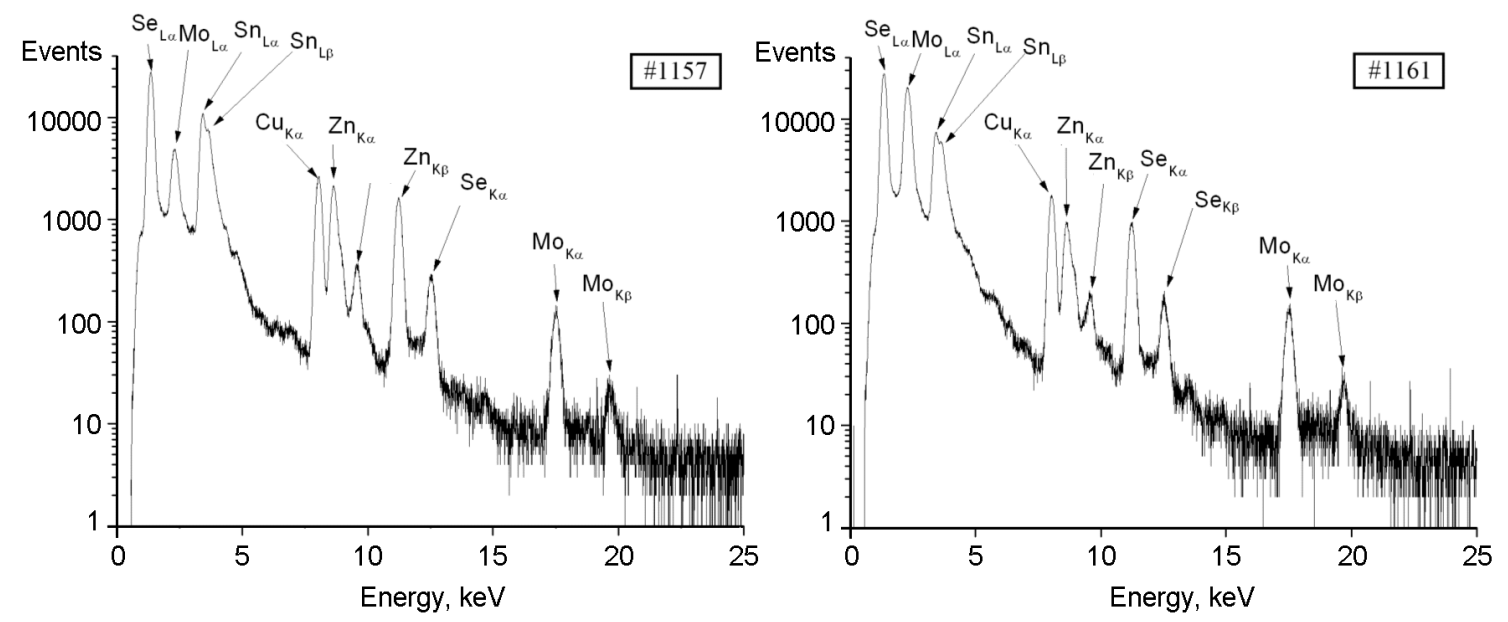

Fig. 3. Total PIXE spectra from the CZTSe films induced by exposure to a proton beam.

the first and fourth iterations; the latter yielded the most accurate values.

We found that the CZTSe lattice parameters are in the ranges of $a=(0.56640-$ $0.56867) \mathrm{nm}, c=(1.13466-1.13776) \mathrm{nm}$, $c / 2 a=0.9983-1.0017$, and $V=(0.3640-$ $0.3675) \mathrm{nm}^{3}$. These values agreed reasonably well with the reference data $(a=$ $0.56930 \mathrm{~nm}, c=1.13330 \mathrm{~nm}, \quad c / 2 a=$ $0.9954, V=0.3673 \mathrm{~nm}^{3}$ ) [18], and those presented in [26] for single-crystal material $(a=0.56882 \mathrm{~nm}, c=1.13379 \mathrm{~nm}, c / 2 a=$ $0.9966, V=0.3668 \mathrm{~nm}^{3}$ ).

The films showed some textured growth along [211], the existence of which was confirmed by our calculations of the inverse pole figures. The pole density $P_{i}$ has the largest value for the crystallographic plane (211) of the tetragonal phase.

The analysis of the values for the orientation factor $f$ (Table 2) suggests that the most textured samples are $1152(f=6.16)$ and 1161 ( $f=2.17)$. Samples 1156 and 1157 have almost the same quality of textures.

Table 2 shows the results of our determination of the CSR size by reflections from the crystallographic planes (112) (211), (204), (312), and (316). They are in the ranges of $L_{(112)}=(40.8-48.4) \mathrm{nm}, L_{(211)}=$ $(20.0-34.9) \mathrm{nm}, \quad L_{(204)}=(28.5-32.7) \mathrm{nm}$.
The maximum value in sample 1156 indicates depletion of $\mathrm{Cu}$ and $\mathrm{Zn}$.

The typical PIXE spectra depicted in Fig. 3 (on the logarithmic scale) were obtained from random areas of the CZTSe film's surface after proton beam irradiation. As is evident, the spectra contain only the lines from the component compounds $(\mathrm{Cu}, \mathrm{Zn}, \mathrm{Sn}$, and $\mathrm{Se}$ ) and the sub-layer Mo.

Processing the experimental spectra revealed the mass concentration of the constituent elements of the CZTSe films. Table 3 contains the corresponding results for a series of samples obtained under different physical conditions of deposition. From these results, we calculated the atomic concentrations of the components in the samples and the ratio $C_{\mathrm{Cu}} / C_{(\mathrm{Zn}+\mathrm{Sn})}$. The $C_{\mathrm{Zn}} / C_{\mathrm{Sn}}$ ratio is used for determining the stoichiometry of the compounds. This table gives the mean values for calculating these ratios. As noted earlier, we collected measurements at several points on the sample's surface. We note that the accuracy of the method of assessing changes in the solid solution in the area of the films was verified.

Table 3 shows that the physical conditions of deposition determined the composi-

Table 3. The results of analysis elemental composition by the PIXE method

\begin{tabular}{|c|c|c|c|c|c|c||}
\hline Sample & $C_{\mathrm{Cu}}$ at. $\%$ & $C_{\mathrm{Zn}}$ at. $\%$ & $C_{\mathrm{Sn}}$ at. $\%$ & $C_{\mathrm{Se}}$ at. $\%$ & $C_{\mathrm{Cu}} / C_{(\mathrm{Zn}+\mathrm{Sn})}$ & $C_{\mathrm{Zn}} / C_{\mathrm{Sn}}$ \\
\hline 1161 & 19.45 & 12.41 & 54.24 & 13.91 & 0.74 & 0.89 \\
1156 & 16.81 & 17.57 & 52.52 & 13.11 & 0.55 & 1.34 \\
1152 & 22.11 & 7.44 & 51.66 & 18.79 & 0.84 & 0.40 \\
1157 & 18.03 & 17.70 & 47.91 & 16.36 & 0.53 & 1.08 \\
\hline
\end{tabular}



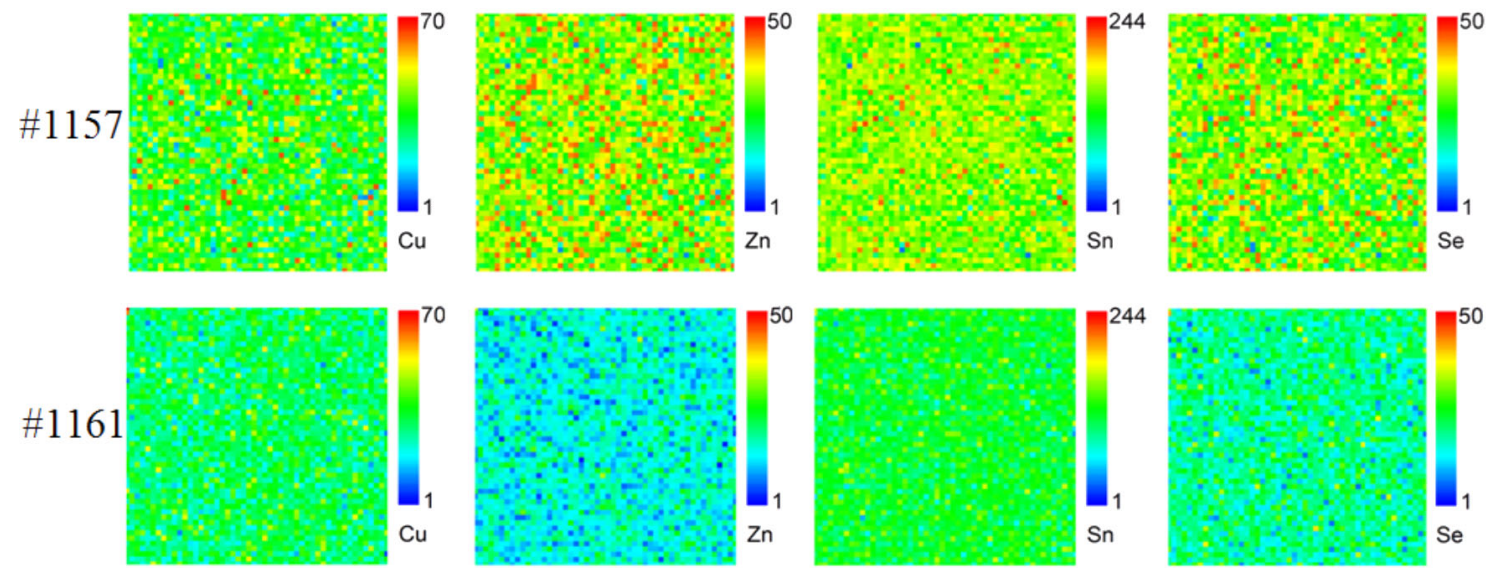

Fig. 4. Elemental distribution maps in samples sized $200 \times 200 \mu \mathrm{m}^{2}$ (grid $50 \times 50$ pixels, scanning step $4 \mu \mathrm{m})$.
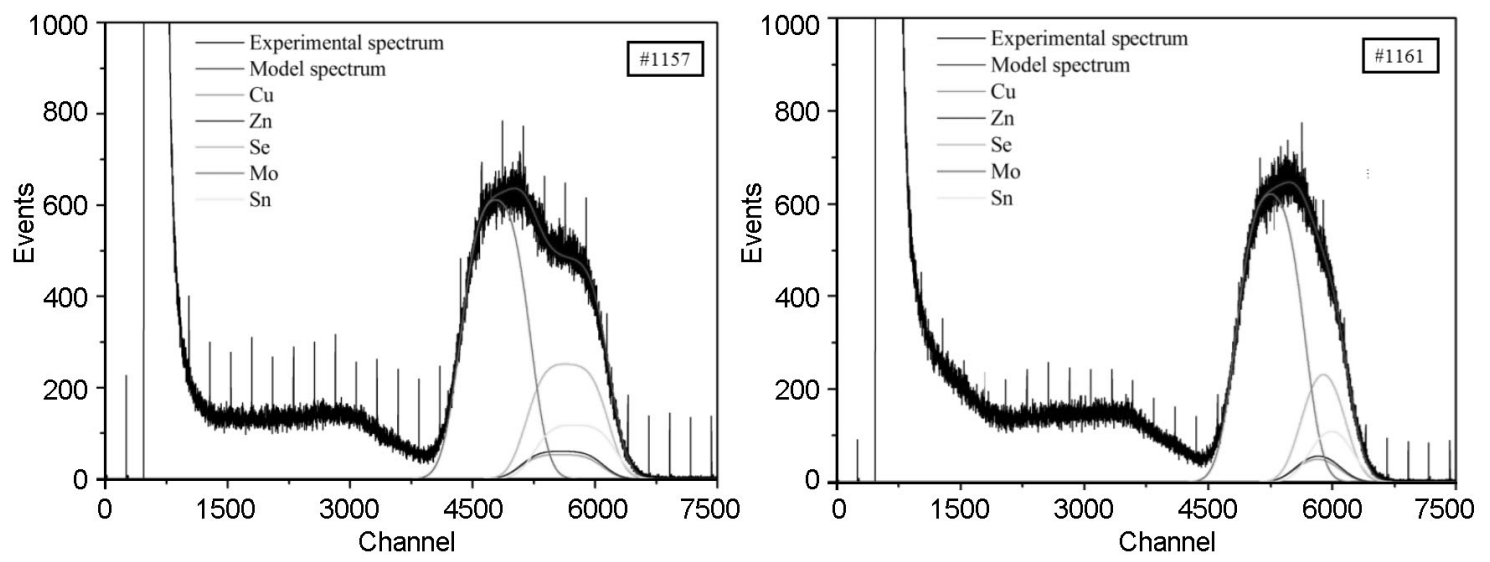

Fig. 5. RBS energy spectra of protons from the CZTSe samples. The dotted line — simulation spectrum.

tion which differ from the estimated values in Table 1.

Figure 4 shows maps of the elements' distribution on the samples' surfaces. Here, the scale in each pixel indicates the quantum characteristic X-ray intensities induced by the focused proton beam's energy corresponding to the $\mathrm{K}_{\alpha}$-peak elements in the spectrum (Fig. 3). We found that the difference of $\mathrm{X}$-ray radiation in each pixel is at an acceptable level of statistical variation. So we can say that the components of the compound divided by the area of the samples is fairly uniform.

To improve the reliability of the results, we used the method of RBS. The typical scattering spectra of the condensates are shown in Fig. 5.

Fig. 5 shows that the peaks of copper, tin, zinc, and selenium in the RBS spectra overlap with those in [2] one on one. It was not possible to determine the elemental composition of the thin films with the accuracy required by this method and build a distribution of elements through the thickness of layers, as was done earlier for films of $\mathrm{ZnS}$ [25]. However, the analysis of the RBS spectra allowed us to determine the films' thickness. The corresponding results are given in Table 1.

\section{Conclusions}

$\mathrm{Cu}_{2} \mathrm{ZnSnSe}_{4}$ thin films were obtained by co-evaporating the components $(\mathrm{Cu}, \mathrm{Zn}$, Sn, and Se) using an electron beam evaporation system, where Se were thermally evaporated for high deposition rate. The samples were investigated by scanning electron microscopy, X-ray, PIXI and RBS analyses. $\mathrm{X}$-ray analyses showed that the all films are practically single-phased and contain the CZTSe compound, which has a tetragonal lattice with the kesterite structure. The samples have textural growth of [211]. The lattice parameters of the material varied in 
the range of $a=(0.56640-0.56867) \mathrm{nm}, c=$ (1.13466-1.13776) $\mathrm{nm}$, and $c / 2 a=0.9983-$ 1.0017, which correspond to the reference data for CZTSe compound. The values of the CSD size in the films varied in the range of $L_{(112)}=(41-48) \mathrm{nm}$. The distribution maps of elements on the surface were obtained, and it was determined that the elemental composition of the films depend on the deposition conditions. It is found that it differs from the expected calculation. The $\mu$-PIXE method shows that the distribution of components on the films surface is homogeneous.

Acknowledgments. This work is supported by the Ukraine State Agency for the Science, Innovation and Information, and by the Ministry of Education and Science of Ukraine (Grant No. 0113U000131) and by the National Research Foundation of Korea (NRF) funded by the Ministry of Science, ICT and Future Planning (MSIP) of Korea (No. 2011-0019204).

\section{References}

1. I.S.Babichuk, V.O.Yukhymchuk, V.M.Dzhagan et al., Functional Materials, 20, 186 (2013).

2. G.S.Babu, Y.B.K.Kumar, P.U.Bhashkar et al., J.Phys. D: Appl.Phys., 41, 205305 (2008).

3. J.J.Scragg, P.J.Dale, L.M.Peter et al., Phys. Status Solidi B, 245, 1772 (2008).

4. A.S.Opanasyuk, D.I.Kurbatov, H. Cheong et al., J.Nano- and Electron. Phys., 4, 01024-1 (2012).

5. M.Ganchev, J.Iljina, L.Kaupmees et al., Thin Solid Films, 519, 7394 (2011).

6. A.Redinger, K.Hones, X.Fontane et al., Appl. Phys. Lett., 98, 101907-1 (2011).

7. J.Li, T.Ma, M.Wei et al., Appl. Surf. Sci., 258, 6261 (2012).

8. D.B.Mitzi, O.Gunawan, T.K.Todorov et al., Solar Energ, Mat., 95, 1421 (2011).

9. K.Wang, B.Shin, K.B.Reuter et al., Appl. Phys. Lett., 98, 051912-1 (2011).
10. W.Wang et al., Adv.Energy Mat., DOI: 10.1002/aenm.201301465 (2013).

11. T.K.Todorov, J.Tang, S.Bag et al., $A d v . E n$ ergy Mat., 3, 34 (2013).

12. B.Schubert, B.Marsen, S.Cinque et al., Prog. Photovoltaics, 19, 93 (2011).

13. G.Zoppi, I.Forbes, R.W.Miles et al., Progr. in Photovoltaics: Research and Applications, 17, 315 (2009).

14. L.Guo, Y.Zhu, O.Gunawan et al., Progress in Photovoltaics: Res. and Appl., DOI: 10.1002/pip.2332 (2013).

15. S.Y.Kim, J.H.Kim, Thin Solid Films, DOI: 10.1016/j.tsf.2013.03.094 (2013).

16. S.J.Ahn, S.Jung, J.Gwak et al., Appl.Phys. Lett., 97, 021905-1 (2010).

17. D.Park, D.Nam, S.Jung et al., Thin Solid Films, 519, 7386 (2011).

18. Selected Powder Diffraction Data for Education Straining (Search Manual and Data Cards), Published by the Intern. Centre for Diffraction Data, 432 (1997).

19. B.E.Warren, X-ray Diffraction, Dover Books on Physics, New York (1990).

20. Ja.S.Umanskij, Ju.A.Skakov, A.N.Ivanov et al., Crystallogaphy, X-ray Graph and Electronmicroscopy, Metallurgy, Moscow (1982) [in Russian].

21. V.V. Kosyak, D.I.Kurbatov, M.M.Kolesnyk et al., J.Mater. Chem. and Phys., 138, 731 (2013).

22. M.B.H.Breese, D.N.Jamieson, P.J.C.King, Materials Analysis Using a Nuclear Microprobe, John Wiley \& Sons. Ins., New York (1996).

23. V.E.Storizhko, A.G.Ponomarev, V.A.Rebrov et al., Nucl. Instr. Meth. Phys. Res., 260, 49 (2007).

24. F.Weinberg, Tools and Techniques in Physical Metallurgy, New York, M.Dekker (1973).

25. A.B.Kramchenkov, O.O.Drozdenko, M.I.Zakharets, Metallofizika i Noveishie Tekhnologii, 30, 453 (2008).

26. I.D.Olekseyuk, L.D.Gulay, I.V.Dydchak et al., J.Alloys Comp., 340, 141 (2002). 